\title{
Formulation and Standardization of Trivrutadi Gutika - An Ayurvedic Formulation
}

\author{
Research Article
}

\author{
Keerthy S Namboodiri ${ }^{*}$, Prathviraj Puranik², Nagaratna $\mathrm{J}^{3}$ \\ 1.PG Scholar 2.HOD \& Professor 3. Assistant Professor \\ Department of PG studies in Kaumarabhritya, \\ Sri Dharmasthala Manjunatheshwara College of Ayurveda and Hospital, Udupi.
}

\begin{abstract}
Trivrutadi gutika, is an Ayurvedic formulation described in Chakradatta which is useful in conditions such as Udavarta(reverse movement of vata), Vibandha(constipation)etc. It contains ingredients such as Trivrut, Pippali, Haritaki and Guda. It is prepared according to the standard Gutika Kalpana along with modern techniques of Tableting. In the present era, as the changing trends necessitated the establishment of standards for Ayurvedic drugs $\&$ formulations and development of reliable quality protocols using modern techniques of analysis is extremely important. Gutika(tablet) is standardised by different physicochemical parameters and chromatographic examination including HPTLC fingerprinting. All the parameters like uniformity of weight, loss on drying, disintegration time, friability, hardness, total ash, water soluble ash and acid insoluble ash were well within the norms specified by the Indian Ayurvedic Pharmacopeia with respect to a tablet.
\end{abstract}

Key Words: Trivrutadi gutika, Childhood constipation, Physicochemical analysis, HPTLC profile

\section{Introduction}

Ayurveda is one of the oldest healing system of medicines. Drug formulation in Ayurveda is mainly of two kinds- (i)use of sing drug (ii)use of combination of drugs (polyherbal formulation). The different types of formulations described in the field of Ayurveda include Choornas(fine powders), Kwathas (Aqueous extracts), Taila/Grithas (lipid extracts), Gutikas (tablets) to name a few(1-2). The methods of manufacture and protocols for standardization of formulations mentioned in the classical texts of Ayurveda are quite premature, hence in the present era, changing trends have necessitated the establishment of standards for Ayurvedic drugs \& formulations and development of reliable quality protocols for Ayurvedic formulations using modern techniques of analysis is extremely important.

Standardization is an important aspect in maintaining the quality and safety of any polyherbal formulation as these are combinations of more than a herb to attain the desired therapeutic effect and it also helps minimize batch to batch variation (3). A polyherbal Ayurvedic formulation (Trivrutadi gutika) was prepared using different drugs including Operculina turpethum Linn, Piper longum Linn.

\section{* Corresponding Author:}

\section{Keerthy S Namboodiri}

PG scholar,

Department of $P G$ studies in Kaumarabhritya,

Sri Dharmasthala Manjunatheshwara College of

Ayurveda and Hospital, Udupi.

Email id - keerthynamboodiri93@gmail.com
Terminalia chebula Retz. Saccharum officinarum according to the standard gutika/tablet preparation along with modern techniques of Tableting. The present study is an attempt to develop and standardize Trivrutadi gutika and to evaluate its efficacy in childhood constipation (functional in origin). To fulfil the requirement of the emerging trend, the prepared tablet was subjected for standardization as per pharmacopeial norms.

\section{Materials and Methods \\ Collection of Raw drugs}

The materials for the formulation Trivrutadi gutika- Trivrut (Operculina turpethum Linn.), Pippali(Piper longum Linn.), Haritaki(Terminalia chebula Retz.), Guda(Saccharum officinarum) were procured and manufactured by AVN Ayurveda Formulations Pvt.Ltd. Madurai, TamilNadu, India and was authenticated at the in house quality control department. The prepared tablet was then subjected for characterisation and HPTLC finger printing.

\section{Preparation of Trivrutadi Gutika}

The raw materials were procured and were checked for the quality by comparing their HPTLC profiles against an in-house standard. The different parts of the plant used for the preparation (Table 1) were then washed thoroughly with running water to remove all physical impurities (sand/mud) and dried for one day under sunlight. The dried ingredients along with Guda(Jaggery) was then powdered in a blender and sieved using an electric sieve having 100 microgram mesh size separately. All the uniformly micronized 
powders were then mixed. To this mixture, binding and disintegration agents (Aerosil 0.050kg, Magnesium stearate $0.010 \mathrm{~kg}$, Maize starch $0.940 \mathrm{~kg}$ etc) were added. By using tablet punching machine, the powder is converted into tablets weighing $500 \mathrm{mg}$ each.

Table 1: Part of the plant used in the preparation of formulation

\begin{tabular}{|c|c|c|c|}
\hline SI No & $\begin{array}{c}\text { Name of } \\
\text { plant }\end{array}$ & $\begin{array}{c}\text { Part used in the } \\
\text { preparation }\end{array}$ & $\begin{array}{c}\text { Proportio } \\
\text { n }\end{array}$ \\
\hline 1 & Trivrut & Moola (Root) & 90 grams \\
\hline 2 & Pippali & Phala (Fruit) & 180 grams \\
\hline 3 & Haritaki & Phala (Fruit) & 230 grams \\
\hline 4 & Guda & ---- & 500 grams \\
\hline
\end{tabular}

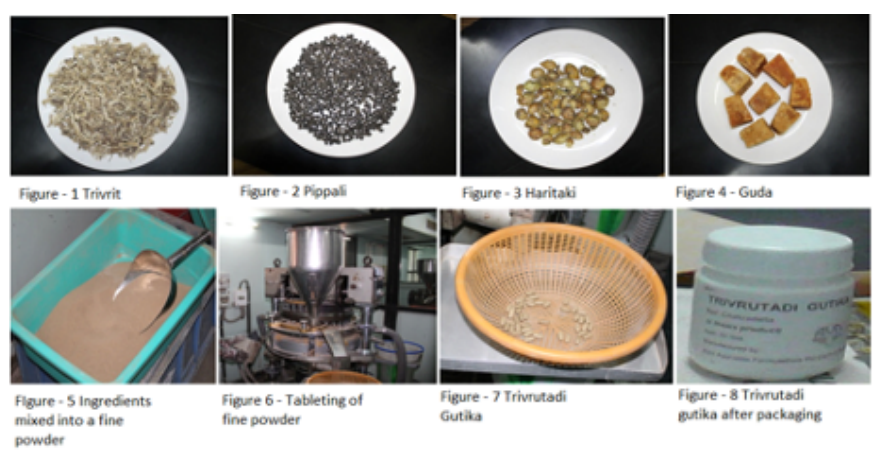

Analytical study of Trivrutadi gutika

ORGANOLEPTIC EVALUATION

1.COLOR- Blackish brown colour

2.ODOUR- Characteristic odour

3.TASTE- Astringent

4.SIZE \& SHAPE- Dimensionally, it is $20.0 \mathrm{~mm}$ length, $9.30 \mathrm{~mm}$ width, $7.50 \mathrm{~mm}$ thickness which falls within \pm $5 \%$ variation of the standard value. The shape of the tablet was - elongated bi-convex.

\section{PHYSICO-CHEMICAL ANALYSIS}

1. Twenty tablets were randomly selected and weighted individually on Shimadzu electronic analytical balance. The average weight was measured, and the percentage of deviation was calculated using the following formula.

$$
\begin{aligned}
\text { Deviation }(D) & =\mid \text { Tablet weight }- \text { Average weight } \mid \\
D \% & =\frac{D}{\text { Average weight }} \times 100
\end{aligned}
$$

As per USP standards, individual weights of two tablets should not deviate from the average weight by $5 \%$ and none deviated by $10 \%$ (4).

1.Hardness: Hardness is the measure of the mechanical integrity of the tablets. It is the force required to break the tablets in a specific plan. Tablet requires a certain amount of strength or hardness and resistance to withstand mechanical shakes of handling in manufacture, packaging and shipping. The randomly selected tablets were tested individually using Pfizer tablet hardness tester. The tablet was held vertically in between the jaws of hardness tester. The force applied to the edge of the pill was gradually increased by pressing the jaws with the help of hand until the tablet breaks. The reading was recorded, and the average hardness of each group was calculated separately. The reading is expressed as $\mathrm{Kg} / \mathrm{Cm}^{2}$ or in Newton (N)(4).

2. Friability: One of the commonly employed test to measure the ability of tablets to withstand mechanical stresses determines their resistance to chipping and surface abrasion by tumbling them in a rotating drum. The percentage weight loss after tumbling is referred to as the friability of the tablets. The friability test is conducted in the Roche friability apparatus by taking 20 tablets. This consists of a plastic drum that revolves at $25 \mathrm{rpm}$, dropping the tablets through six inches in the friabilator to undergo shock, which is then operated for 100 revolutions. The tablets are reweighed. The tablet that lose less than $1.0 \%$ of the tablet weight are considered as acceptable (4).

3. Loss on drying: This procedure determines the amount of volatile matter or water present in the drug. For a stable shelf life, the moisture content should be below $2 \%$. The moisture present in the product is also known as water activity. Higher water activity is directly proportional to microbial growth such as yeast, mould and bacteria. The LOD is determined by moisture balance equipped with an infra-red lamp. To determine the LOD, about $2 \mathrm{~g}$ of drug is kept on the moisture balance and dried at $105^{\circ} \mathrm{C}$ till getting a constant weight and weight between two consecutive time intervals is not more than $0.01 \mathrm{~g}$.

4. Disintegrating time: Disintegration is defined as that state in which no residue of the tablet remains on the screen of apparatus. This test determines whether the tablet disintegrate within a prescribed time when placed in a liquid medium under the prescribed experimental conditions. The tank of the disintegration apparatus was filled with distilled water up to the mark. $750 \mathrm{ml}$ of distilled water in each of the $1000 \mathrm{ml}$ beaker was taken. The timer of the instrument was set for 60 minutes. The temperature of water in beakers to $37^{\circ} \mathrm{C}$ and that of water in the main tank to $37^{\circ} \mathrm{C}$ was maintained. One tablet was introduced into each tube and added a disk to each tube. The assembly was suspended in the beaker containing water and the apparatus was operated. The time duration at which the tablet disintegrates was noted. As per set criteria by USP if 6 tablets are tested, all the 6 tablets should be disintegrated.

5. Total ash: Two grams of coarse powdered air-dried material was accurately weighed in a previously activated and tarred silica crucible. The drug was gradually ignited by raising temperature to $450^{\circ}$ inside a muffle furnace, until it was white, indicating absence of carbon. The sample was cooled in a desiccator and weighed. The percentage of total ash was calculated with reference to air dried drug. A high ash value is indicative of contamination, substitution, adulteration, presence of silica, rice husk or carelessness in preparing the drug. 
6. Acid insoluble ash: The ash was boiled with $25 \mathrm{ml}$ of $2 \mathrm{M}$ hydrochloric acid for 5 minutes, the insoluble matter was collected on an ash less filter paper, washed with hot water till neutral $\mathrm{pH}$, ignited, cooled in a desiccator, and weighed. The percentage of acid insoluble ash was calculated with reference to the airdried drug. A low acid-insoluble ash value affects the amount of the drug component absorbed in the gastrointestinal canal when taken orally.

7. Water soluble ash: The ash was boiled with $25 \mathrm{ml}$ of water for 5 minutes, the insoluble matter on ash less filter paper collected, washed with hot water, ignited, cooled in a desiccator, and weighed. The weight of the insoluble matter from the weight of the total ash was subtracted. The difference represents the water-soluble ash. The percentage of water insoluble ash was calculated with reference to the air-dried drug (5).

8. $\mathbf{p H}: \mathrm{pH}$ is determined by dissolving $2 \mathrm{gm}$ of tablet powder in $100 \mathrm{ml}$ of de-mineralized water at room temperature.

\section{Table 2: Physico-Chemical Properties of Trivrutadi} gutika

\begin{tabular}{|c|c|c|}
\hline Parameter & Observation & Specification \\
\hline Weight & $1.016 \mathrm{gm}$ & $\begin{array}{c} \pm 5 \% \text { of average } \\
\text { weight }\end{array}$ \\
\hline Hardness & $9.0 \mathrm{~kg} / \mathrm{cm}^{2}$ & NLT $10 \mathrm{~kg} / \mathrm{cm} 2$ \\
\hline Loss on drying & $8.20 \%$ & Not more than $10 \%$ \\
\hline $\begin{array}{l}\text { Disintegration } \\
\text { time }\end{array}$ & 45 minutes & $\begin{array}{c}\text { Not more than } 60 \\
\text { minutes }\end{array}$ \\
\hline Total ash & $7.00 \%$ & Not more than $20 \% \pm$ \\
\hline Acid insoluble ash & $2.96 \%$ & Not more than $10 \%$ \\
\hline Water soluble ash & $3.40 \%$ & Not more than $10 \%$ \\
\hline $\mathrm{pH}$ & 3.81 & 3.0 to 5.0 \\
\hline Friability & $0.49 \%$ & $\begin{array}{c}\text { Not more than } 1 \% \\
\mathrm{w} / \mathrm{w}\end{array}$ \\
\hline
\end{tabular}

\section{HPTLC}

The above plant materials along with their corresponding formulation Trivrutadi gulika were extracted with alcohol based on their phytochemical composition. TLC was developed for all samples in an optimized solvent system of Toluene: Ethyl acetate: Methanol in an optimized composition of 7:2:1.100mg/ $\mathrm{ml}$ of sample solution was prepared in methanol and filtered through the $0.45 \mu \mathrm{m}$ membrane filter. Each of sample was spotted at 101 volume, by Linomat 5 applicator on pre-coated silica gel plate (silica gel-60 $\mathrm{F}_{254)}$-Merck) from $1 \mathrm{~cm}$ above the plate. $100 \mu 1$ capacity Hamilton ${ }^{\circledR}$ syringe was used for sample loading. TLC plate was run in the CAMAG TLC $10 \times 10$ chamber. Before running the TLC, the chamber was saturated with the solvent for 10 minutes with paper lining of the chamber. Then the TLC was run for 8 minutes from application band. In completion of the run the TLC was dried vertically and visualized in the UV chamber to check the resolution and analysed in CAMAG TLC scanner 3 and software win CATS 1.4.3 (6).

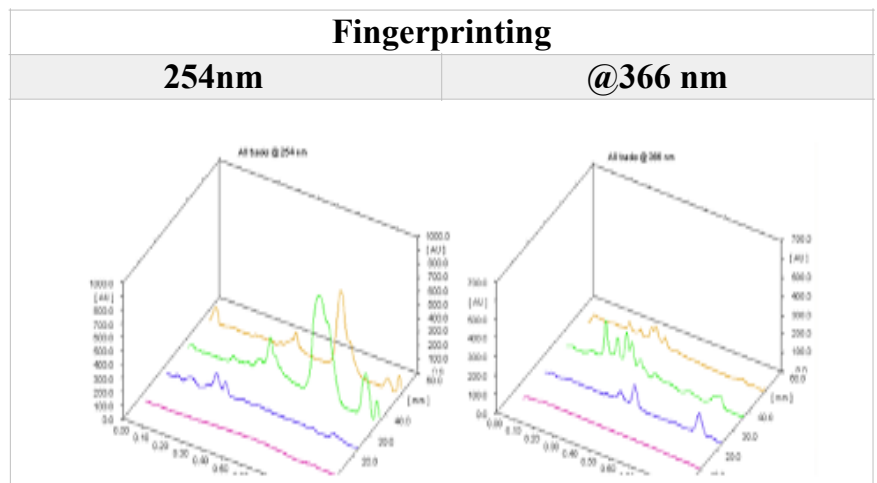

Figure 9 - Fingerprinting of Trivrutadi Gutika at $245 \& 366 \mathrm{~nm}$

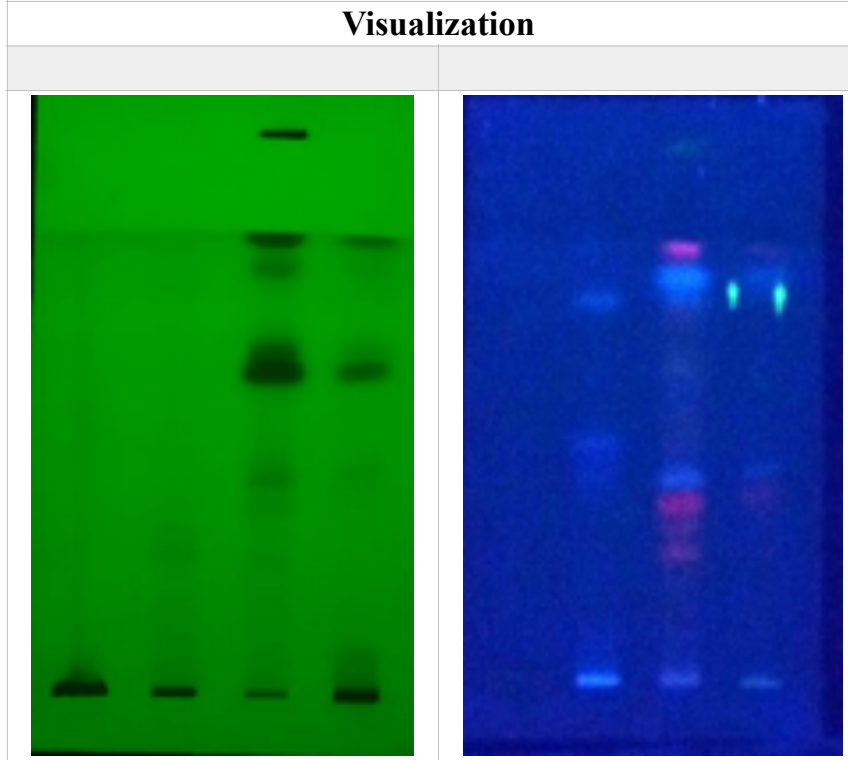

Figure 10 Visualisation under 245 and 366 nm

\section{PEAK DISPLAY}

\section{TLC densitogram @ 254nm}

Figure 11 - Terminalia chebula

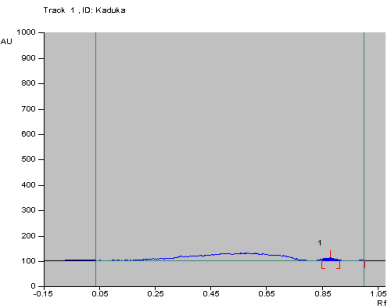

Figure 12 - Operculina turpethum

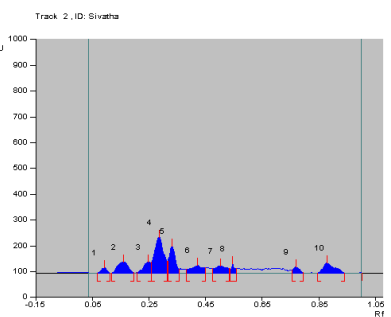

Figure 14 - Piper longum

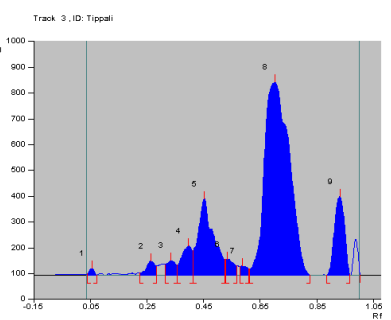

Figure 15 - Trivrutadi Gutika

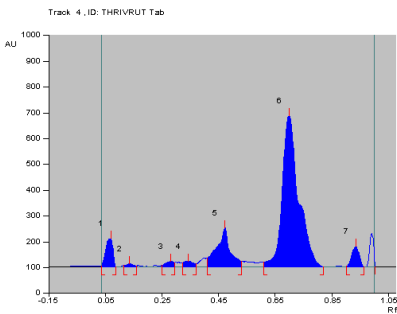




\section{TLC densitogram@366nm}

Figure 16 - Terminalia chebula

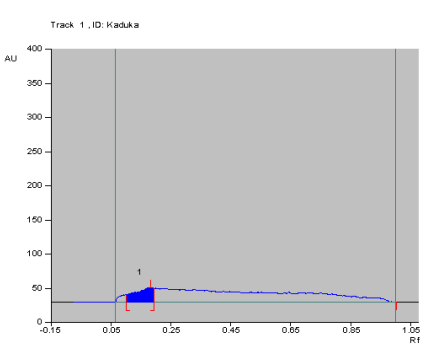

Figure 17 - Operculina turpethum

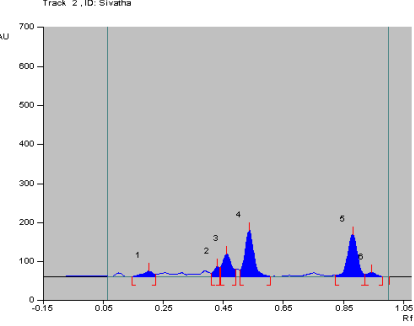

Figure 18 - Piper longum

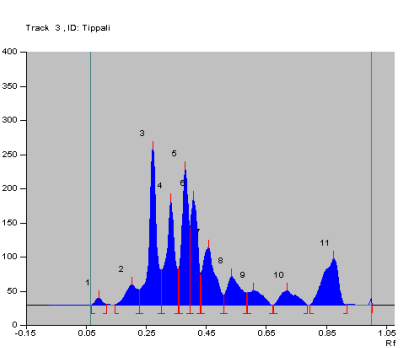

Figure 19 - Trivrutadi Gutika

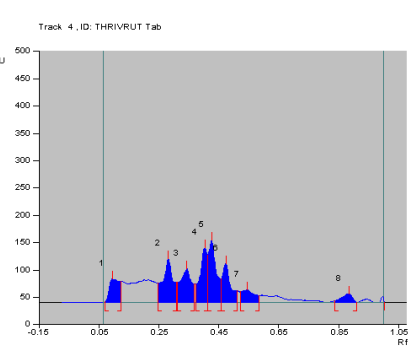

Table no 3: Showing the $R f$ value and Area at $254 \mathrm{~nm}$

\begin{tabular}{|c|c|c|c|c|c|c|c|c|}
\hline \multirow{3}{*}{$\begin{array}{c}\text { Peak } \\
\text { Samples }\end{array}$} & \multicolumn{8}{|c|}{ @254nm } \\
\hline & \multicolumn{4}{|c|}{$R_{f}$ Value } & \multicolumn{4}{|c|}{ Area (AUC) } \\
\hline & $\begin{array}{c}\text { Terminalia } \\
\text { chebula }\end{array}$ & $\begin{array}{l}\text { Operculina } \\
\text { turpethum }\end{array}$ & $\begin{array}{c}\text { Piper } \\
\text { longum }\end{array}$ & $\begin{array}{l}\text { Trivrutadi } \\
\text { gutika }\end{array}$ & $\begin{array}{l}\text { Terminalia } \\
\text { chebula }\end{array}$ & $\begin{array}{l}\text { Operculina } \\
\text { turpethum }\end{array}$ & $\begin{array}{c}\text { Piper } \\
\text { longum }\end{array}$ & $\begin{array}{l}\text { Trivrutadi } \\
\text { gutika }\end{array}$ \\
\hline 1 & 0.91 & 0.11 & 0.07 & 0.08 & 322.20 & 316.70 & 350.70 & 2078.70 \\
\hline 2 & & 0.19 & 0.28 & 0.16 & & 1233.80 & 1294.30 & 234.70 \\
\hline 3 & & 0.25 & 0.35 & 0.29 & & 842.30 & 1364.50 & 468.90 \\
\hline 4 & & 0.31 & 0.41 & 0.37 & & 3400.80 & 3202.70 & 602.80 \\
\hline 5 & & 0.35 & 0.52 & 0.53 & & 1693.60 & 11942.10 & 5330.20 \\
\hline 6 & & 0.45 & 0.56 & 0.82 & & 975.30 & 1402.10 & 25414.30 \\
\hline 7 & & 0.53 & 0.61 & 0.96 & & 900.70 & 671.30 & 1596.50 \\
\hline 8 & & 0.56 & 0.82 & & & 366.90 & 49460.40 & \\
\hline 9 & & 0.79 & 0.960 & & & 405.10 & 8191.70 & \\
\hline 10 & & 0.94 & & & & 1186.80 & & \\
\hline
\end{tabular}

Table no 3: Showing the Rf value and Area at $366 \mathrm{~nm}$

\begin{tabular}{|c|c|c|c|c|c|c|c|c|}
\hline \multirow{3}{*}{$\begin{array}{c}\text { Peak } \\
\text { Samples }\end{array}$} & \multicolumn{8}{|c|}{ (a)366nm } \\
\hline & \multicolumn{4}{|c|}{$\mathbf{R}_{\mathrm{f}}$ Value } & \multicolumn{4}{|c|}{ Area (AUC) } \\
\hline & $\begin{array}{l}\text { Terminalia } \\
\text { chebula }\end{array}$ & $\begin{array}{l}\text { Operculina } \\
\text { turpethum }\end{array}$ & $\begin{array}{c}\text { Piper } \\
\text { longum }\end{array}$ & $\begin{array}{c}\text { Trivrutadi } \\
\text { gutika }\end{array}$ & $\begin{array}{l}\text { Terminalia } \\
\text { chebula }\end{array}$ & $\begin{array}{l}\text { Operculina } \\
\text { turpethum }\end{array}$ & $\begin{array}{c}\text { Piper } \\
\text { longum }\end{array}$ & $\begin{array}{c}\text { Trivrutadi } \\
\text { gutika }\end{array}$ \\
\hline 1 & 0.18 & 0.20 & 0.09 & 0.09 & 995.10 & 373.80 & 176.40 & 1110.70 \\
\hline 2 & & 0.43 & 0.20 & 0.28 & & 384.50 & 893.60 & 1931.60 \\
\hline 3 & & 0.46 & 0.27 & 0.34 & & 1294.40 & 4158.80 & 1669.80 \\
\hline 4 & & 0.53 & 0.33 & 0.40 & & 2665.60 & 3146.20 & 1737.50 \\
\hline 5 & & 0.88 & 0.38 & 0.42 & & 2647.40 & 3277.70 & 2197.90 \\
\hline 6 & & 0.94 & 0.40 & 0.47 & & 241.60 & 2616.20 & 1435.90 \\
\hline 7 & & & 0.45 & 0.54 & & & 2557.60 & 749.50 \\
\hline 8 & & & 0.53 & 0.88 & & & 1381.50 & 419.30 \\
\hline 9 & & & 0.60 & & & & 760.00 & \\
\hline 10 & & & 0.72 & & & & 853.80 & \\
\hline
\end{tabular}

\section{Results and discussion}

Visibly the TLC fingerprint of the Gutika showed presence of the bands from extracts of TC, OT and PL. Further both the above chromatogram and densitogram showed the overlapping bands of the all the individual constituents with that of the finished product formulation. The finished product Trivrutadi gutika-TG showed corresponding bands from Operculina turpethum-OT and Piper longum-PL at Rf of $0.11,0.19$ and 0.25 for OT and at 0.52 and 0.96 from PL. At $366 \mathrm{~nm}$ the bands from PL were more prominent at Rf $0.27,0.33,0.40,0.45,0.53$ and 0.88 from PL with corresponding bands at $0.28,0.34,0.40$ and $0.42,0.54$ and 0.88 in the TG formulation. At $366 \mathrm{~nm}$ OT showed that bands at 0.88 which matches with the TG at the same Rf. The slight variation of the Rf value may be complexity of the formulation in TG and compoundcompound interaction with the TLC stationary phase. Therefore, above HPTLC study can be used as quality control parameter for study of the finished product formulation as well as to determine the authenticity and reliability of the chemical constituents or herbal constituents as mentioned in their label claim.

Further all other parameters like uniformity of weight, loss on drying, disintegration time, friability, hardness, total ash, water soluble ash and acid insoluble ash were well within the norms specified by the Indian Ayurvedic Pharmacopeia with respect to a tablet. Hence it can be deduced that if the raw materials sourced are put under rigorous quality control and if there are strict in process controls in the manufacture of a formulation, the likelihood for batch to batch variation and production of an ineffective formulation is very meagre(7-9).

\section{Conclusion}

The raw materials required for the production of Trivrutadi gutika were characterised by HPTLC 
fingerprinting and compared vis-à-vis an in-house standard and all the manufacturing steps were tightly controlled followed by characterization of the formulation as mentioned in the Indian Pharmacopeia. In addition to the characterization norms set in the Indian Pharmacopeia, HPTLC fingerprinting was done to compare and elicit the presence of the various actives of the raw-materials in the finished product, results of which suggest that several active ingredients present in the raw-materials are seen in the final formulation there by suggesting that the desired action of efficacy of the drug be ensured.

The data thus obtained can be used to conclude that standardisation of the manufacturing process and standardisation of the raw materials will be helpful in reproducibility of formulations as well as to ensure the quality and safety of the formulations.

\section{References}

1. Savrikar, SS;Ravishankar B. Bhaishajya Kalpana The Ayurvedic Pharmaceutics-An Overview. Afr J Tradit Complement Altern Med, 2010; 7(3); 174-184.

2. Rahi Jain, Padma Venkatasubramanian. Proposed correlation of modern processing principles for Ayurvedic herbal drug manufacturing: A systematic review. Ancient Science of Life. 2014; 34(1); 8-15.

3. Subramani Parasuraman, Gan Siaw Thing, Sokkalingam Arumugam Dhanaraj. Polyherbal formulation: Concept of ayurveda. Pharmacogn Rev. 2014;8(16); 73-80.

4. Indian Pharmacopoeia, Pharmaceutical Methods, Pharmaceutical methods, Vol-I, Government of India, Ministry of health and family welfare, publisher-The Indian Pharmacopeia Commission, Ghaziabad, 2010, pp185-197.

5. The Ayurvedic Pharmacopoeia of India, Government of India, Ministry of Health and Family welfare, Department of Ayurveda, Yoga, and Naturopathy, Unani, Siddha and Homeopathy (AYUSH), New Delhi, 2009, Part-I, Vol-VI, pp 242-244.

6. Jayachandran Nair C V, Sayeed Ahamad, Washim Khan, Varisha Anjum, Rajani Mathur, Development and validation of High-performance Thin-layer Chromatography Method for Simultaneous Determination of Polyphenolic Compounds in Medicinal Plants. Pharmacognosy Res. 2017 Dec; 9 (Suppl 1); S67-S73.

7. Divya Pillai, Nancy Pandita. Determination of quality standards for Draksharishta, a polyherbal ayurvedic formulation. Indian $\mathrm{J}$ Pharm Sci 2016;78(1);129-135.

8. Bhakti J. Ladva, Vijay M. Mahida, Urmi D. Kantaria,Rina H. Gokani.Marker based standardization of polyherbal formulation (SJTDI-02) by high performance thin layer chromatography method. J Pharm Bioallied Sci. 2014, 6(3): 213-219. 